Agnieszka Parlińska

Warsaw University of Life Sciences - SGGW, Poland

Lilya Avetisyan

Eurasia International University, Armenia

\title{
THE ROLE OF LEASING IN FINANCING OF INNOVATION IN EUROPE AND ARMENIA
}

The paper presents possibilities of the use of leasing as an instrument of financing of innovation activities. At present times the issue of search of new ways of financial provision for innovation activity, which is the main factor of competitiveness of the enterprises, is of a particular importance. In the paper advantages of the leasing funding mechanism for innovation activities are presented, and the role of innovative leasing in modern conditions is revealed. The comparative analysis of regulation of leasing in a number of European countries is carried out, and also the analysis of the European leasing market is submitted. The structure and current trends of development of the domestic leasing market are considered. The main problems interfering development of leasing in Armenia are revealed. On the basis of the best European practices recommendations are provided, which will promote the use of leasing for stimulation of innovation activities of the enterprises in Armenia.

Key words: leasing, innovation, financing, investment, research and development

\section{Introduction}

In modern conditions the industrial enterprises which are engaged in release of new types of products for the purpose of ensuring survival have to possess great flexibility and ability to update the range of goods quickly. More than ever before, it is necessary to pay special attention to acceleration of turnover of current assets, reduction of excessive stocks, the maximum speed of product sales. It is especially vital at the present stage of development of the industry in Armenia when needs of the industrial enterprises for carrying out modernization of the fixed assets constantly grow. Therefore, with the purpose to conform to high requirements of modern economy, investments are necessary for Armenian enterprises. Along with traditional forms of investment its special form leasing is of great interest which owing to opportunities inherent in it can become an impulse of technical re-equipment of the main production facilities focused on release of innovative types of products.

The aim of this research was to assess the possibilities of the use of leasing as an instrument of financing of innovation activities in Armenia compering to the European best practices. Analyses, carried out in the paper, cover the period of 2009-2014. The data about theoretical and financial issues, use of leasing as an instrument of financing of innovation activities, were taken from the official sources and the applicable literature, legal acts and official statistic of banks and leasing institutions. The descriptive and 
comparative methods were used in the research paper, as well as the simple statistical method in order to analyse the problem from the economic point of view.

\section{Leasing as an instrument of financing of innovation activities}

Innovation activity is, as a rule, characterised by rather high degree of uncertainty and risk therefore the important principles of system of financing of innovation are plurality of sources, flexibility and adaptability to quickly changing environment of innovation processes.

The enterprises, financial and industrial groups, small innovative business, investment and innovation funds, local authorities, individuals etc. can be sources of financing of innovation activities. All of them participate in economic process and promote development of innovation activity.

Leasing serves as an effective form of financing of investments on acquisition of fixed assets for innovation activities. Thus leasing is a transfer to rent (as a rule, longterm and medium-term) means of production, buildings and constructions on the conditions of return, term and payment with opportunity their subsequent sale to the tenant for agreed price, taking into account the sums which are earlier paid for rent. The user (the tenant, the leasing recipient) finds the enterprise where the corresponding equipment is made, or other organization having in ownership material values (property) necessary for the tenant, and gives an assignment to the leasing company to buy this equipment (material values) to provide it in temporary use. ${ }^{1}$

The relations of the parties are formalised by the leasing contract in which are caused: the sum and period of validity of the agreement, the rent size, interest rate, frequency of payments, residual cost of property upon termination of rent term, terms of return to the leasing company or purchase of the leased property after the expiry of action of the contract. During action of the contract the leased property belongs on the property right to the leasing company, and the right of use of this property - to the leasing recipient. ${ }^{2}$

The main forms of leasing are internal leasing (both parties of the contract are residents) and international leasing (one of the parties is a non-resident). It should be noted that the international leasing can represent an effective form of cooperation for the innovative enterprise since thus for reorganization of production and its transfer to more effective technology and manufacture of new product meeting the requirements of the international market it is not required initial allocation of large means in foreign currency. All expenses on acquisition of necessary fixed assets at the first stage of introduction of new technology are covered by the leasing company (lessor). ${ }^{3}$

Remarketing agreement between the lessor and the supplier is more often applied. It is the most widespread form of the guarantee for the supplier of leasing operations. According to this guarantee the supplier assumes the obligation to resell the equipment after its withdrawal at the lessee in case of violation by the lessee the terms of the leasing contract. Responsibility for withdrawal and return of the equipment lies on the lessor

\footnotetext{
${ }^{1}$ T. Clark, Leasing Finance, 3nd ed., 275 pp. Publisher: Euromoney Publications, PLC Pub. Date: January 2004.

${ }^{2}$ Lease and Hire Purchase Contracts, UK GAAP, 7th ed., L.: Ems and Young, 2006, 428p.

${ }^{3}$ International leasing finance seminar. Euromoney - London - 2008 -114p.
} 
though the supplier can make it. After dismantle of the equipment the supplier transports it on a warehouse for storage and carrying out a preparatory work for the purpose of the subsequent realization. After resale of the equipment the supplier pays to the lessor sales proceeds minus expenses on dismantle, storage of the equipment and the small repeated realization commission. The supplier is interested in the conclusion of the contract on repeated realization (on remarketing) because, first of all, it promotes the conclusion of the transaction of purchase and sale with the leasing company as for the leasing company the guarantee of the supplier about repeated realisation is often one of the main conditions of the conclusion of the transaction. Besides, remarketing agreement allows the supplier to control sale of the equipment in the secondary market, makes additional profit, does not comprise additional financial risks. At the conclusion of the leasing contract, a contractor can act as the "captive" leasing company. The company which is established by a producer or a trading company (a seller of an asset) for financing of sales or lease of the made or available products to end users ${ }^{4}$.

Besides above offered there is such concept as securitization of leasing assets for innovative projects. It is a mechanism for receiving rather cheap sources of financing of leasing operations. When the portfolio of leasing contracts reaches enough large sizes, the lessor sells it entirely or partially to newly formed company, for what receives payment from this company. The stocks or bonds emitted for acquisition of the leasing portfolio become a source of means for payment. The new owner of the portfolio gets and distributes receipts from leasing transactions. The investors, who got securities of the new company, receive a share from leasing receipts. As a result of this operation risks for investors decrease as the new company possesses a clear and certain set of assets with rather predictable receipts in the form of leasing payments. Investments are carried out in the concrete, well checked leasing transactions from which payments are made, but not by granting borrowed funds to the leasing company. The former lessor, due to securitization, receives means for new leasing transactions which can be more favourable in comparison with bank credit rates. ${ }^{5}$

Besides, for development of innovative projects the lessor can suggest to conclude the bargain on rates, below market or on the conditions unacceptable for other leasing rival firms on tax or other reasons. It is staked on possibility of receiving high rent payments in the future after competitors are inaccessible to the tenant.

The sources of development of leasing business are the ample opportunities and advantages which can be used by contractors of the leasing transaction on an innovative type of property. Leasing activity can be considered effective: from the position of personal interests - it improves possibilities of satisfaction of material and spiritual needs of businessmen, from the position of collective interests - provides conditions for expanded reproduction; from the position of society - the market is sated with necessary goods and from increase in scales of production of goods receipts in the budget grow in the form of assignments for taxes.

${ }^{4}$ Captive and Vendor Leasing, available at:

http://www.elfaonline.org/cvweb_elfa/Product_Downloads/Captive_Vendor.pdf [accessed: 23.12.2015].

${ }^{5}$ P. Humphreys, H. Mulligan, United States: Lease Securitization: $\bar{N}$ ew Challenges for Issuers, McDermott Will\&Emery, 2005. available at:

http://www.mondaq.com/unitedstates/x/31971/Structured+Finance/Lease+Securitization+New+Challenges+for +Issuers [accessed: 18.12.2015] 
According to a number of scientists (Mehrez A. 1989 and Contino M. Richard 2002, Krinsky I.), for minimization of the risks connected with a leasing object the following methods can be used ${ }^{6}$. For minimization of liquidity risk and interest rate risk it is necessary to avoid mismatch in terms and schedules of assets and liabilities maturity, currency risks can be hedged by means of future transactions.

Considering leasing not as a factor of ensuring innovative activity, and as its independent element, it should be noted that it in many respects depends on the main components of innovation activities - investments and time. .

Moreover, leasing activity in its new quality is defined by the innovative leasing infrastructure representing the sphere of the use of leasing and including the market of novelties (novations), the capital market (investments) and the market of innovations.

Thus, the innovative sphere of leasing represents system of interaction of innovators, investors, producers and the developed investment and leasing infrastructure.

Consumers of leasing services (lessees) treat the first group, which purpose is conducting so-called destructive and creative activity (innovation). It is possible to include in the same group those lessors who provide leasing service ensuring of leasing from a novation to an innovation, though in the majority lessors in the innovative sphere carry out function of investors. Producers of the competitive, demanded in the market of innovative leasing and innovations, in general products which are object of innovation and leasing activities of the first and second groups treat the third group.

As the main subject of innovative leasing relations acts the main link of the economic system - the enterprise lessee (the consumer of leasing services). This circumstance is explained by the fact that the demand of leasing relations as a factor of ensuring innovation activities of the enterprise is only possible in the presence of innovation activity at the enterprise.

The term "innovative leasing", according to a number of authors (Veatch William S. 1996, Crawford Richard D. 2002, Bazrod Mark S. 2006) includes the following kinds of activity:

- Attraction and allocation of financial resources providing innovative activities.

Innovation in this kind of leasing business is that an innovative company, venture firm acts as the lessee under the contract. The leasing object is usually a hi-tech equipment.

- Promotion of an innovative product on the market.

- The nonconventional mechanism of commercialization of objects of intellectual property - the leasing of intellectual property.

The category "innovative leasing" reflects a certain specific type of the economic relations between their subjects: the lessor, the lessee and the seller of leasing property concerning objects of the fixed assets involved in the process of innovation activities.

\footnotetext{
${ }^{6}$ minimization of the risks connected with a leasing object the following methods can ban be use: high advance leasing payment; repurchase agreement with the supplier (Buy Back); remarketing agreement; guarantee of owners and (or) director; additional pledge; signing of the agreement on write-off funds from settlement accounts without acceptance of the lessee (guarantor); possibility of unilateral cancellation of the contract of leasing by the lessor in case of certain violations from the lessee; property insurance of the leasing object which is carried out by the lessor.

${ }^{7}$ E. Durinck K. Jansen, E. Laveren, C. Huile, Leasing and the pie approach to capital structure. Tijdschr. vooreconomieen management. Leuven. - Jg. 35. - № 4, 1990, 387-405.
} 
However not any activity is innovative as it can be either reproductive or productive. In the first case activity is directed on receiving and reproduction of already known traditional material and spiritual benefits (in other words, a product) by earlier known means and ways (in other words, technology). In the second case productive or innovation economic activity is connected:

- $\quad$ or with development and realization of new products by earlier known technologies;

- $\quad$ or with development of known products, but by means of new technologies;

- $\quad$ or with development and realisation of new product by new technology.

In other words, the activity becomes innovative as soon as its purpose or consequence is production, exchange, distribution and consumption of the material benefits possessing novelty.

Thus, innovative leasing can be defined:

1. As the way of investment providing innovation activity.

2. Considering in the domestic economy the process of leasing transition from one quality - novelties (novations) - to another - innovations, - leasing can be accepted as an independent type of innovation activities.

3. As ensuring promotion of an innovative product on the market by means of leasing that is only possible in case leasing gets a bit different than "classically" innovative form or the contents.

\section{Leasing in Europe: legal regulation and market analysis}

The main share of the world leasing market is concentrated in the USA, Western Europe and Japan. In Western Europe the specialised finance (leasing) companies, which are carrying out the role of purely financial character, act as lessors. The leasing companies are controlled by banks or their subsidiaries in $75-80 \%$ of cases, and in the others - by the large industrial companies, suppliers famous in the world market ${ }^{8}$. In the USA, on the contrary, the majority of lessors are largest industrial concerns and their specialised companies. In Japan development of rent operations differs in such a way that leasing companies are not limited to financing of the services connected with rent. Japanese lessors grant services package which can include a combination of purchase and sale, leasing and loans. Such services are called complex leasing.

The sector structure of leasing operations varies depending on the concrete region. So, for example, in Europe leasing of cars and vehicles is widely used. It is followed by leasing of machinery and industrial equipment, computers and business machines, ships, aircraft, rail, etc. The priority of the car leasing in Western Europe is explained that the automobile companies are compelled to look for ways of realization of the products via this mechanism as the most effective. In Western Europe more than $20 \%$ of investments into productive fixed capital assets are carried out through leasing. Thus Great Britain, Germany, France and Italy account for a significant share of leasing business of Western Europe. Transition to a market economy of Poland, Hungary, the Czech Republic, Slovakia and other countries of Eastern Europe, and also CIS countries opened up new possibilities for leasing business.

${ }^{8}$ Leaseurope. Ranking of leasing companies 2014, available at:

http://www.leaseurope.org/uploads/documents/ranking/Leaseurope\%20Ranking\%20Survey\%202014_Public.p df [accessed: 12.01.2016]. 
The leasing market in the USA surpasses countries of Western Europe, and furthermore Eastern Europe and CIS both in scales, and in the level of development ${ }^{9}$. High level of leasing activity in the country is determined: legislative basis; state regulation; macroeconomic situation, conditions of the investment market (investment privileges); level of interest rate, especially taxation, extent of inflation, etc. and the use of accounting system.

Some countries of Western Europe (Great Britain, Germany, Denmark) did not adopt the special legislation on leasing and realise it within the common commercial law, while France, Portugal, Sweden have the special legislation where the rights of the lessor and the lessee, their relationship with producers of the property which is handed over in leasing, are generally specified. ${ }^{10}$ Leasing as a specific form of the economic relations is reflected in the legal document where specifies necessary instructions, the right of trust ownership, the contract of purchase and sale, etc.

Leasing defined in the Accounting Law, the Tax Law and the Civil Code of Poland. ${ }^{11}$ Most of the provisions of the Civil Code regarding leasing agreements have a voluntary character. In consequence the intent of the parties continues to be of key importance in defining the content of such agreements.

France, Belgium and Italy adhere to the concept of the economic owner (as a rule, the option is an indispensable condition of leasing), others (Great Britain, Ireland, Holland, and also the USA) build relationship proceeding from the concept of the beneficial owner. ${ }^{12}$ Besides, some countries of Western Europe are intermediate in the legal relation, having in the legislation elements, characteristic both for one, and for other legal system. In Belgium, Italy, France an indispensable condition of the leasing agreement is sale of the property after the expiry of the term of the agreement on previously coordinated price (option); at the same time in Great Britain and the USA the option is not a leasing condition where rental-sale is provided in the agreement. ${ }^{13}$ Thus, for example, in the USA leasing has a form of the financial transaction used along with the credit and other loans.

The legislation of Germany, Switzerland provides the option which leads leasing to the special type of instalment sale agreement when in case of leasing the owner of property is a lessor, and in case of instalment sale agreement title passes to the recipient at the time of the execution of an agreement. ${ }^{14}$ Leasing differs from rental-sale, instalment sale agreement, secured transaction in economically reasonable amount of

\footnotetext{
9 http://leasing-info.weebly.com/105110801079108010851075-1074-1084108010881077.html [accessed: 20.12.2015].

${ }^{10}$ European Leasing: 2012 New Edition - a Joint Leaseurope/KPMG Asset Finance Tax Network Publication, available at: http://www.leaseurope.org/uploads/EuropeanLeasing_extract(secured)\%20(3).pdf[accessed: 10.01.2016].

11 Leasing Industry in Poland. Leasing Life European Conference, Warsaw 2014, available at: http://www.leasing.org.pl/files/uploaded/Life-prezentacje/8-PLA-Leasing-Life.pdf [accessed: 14.12.2015].

12 Sutton R., 1997. Don't Get Taken Every Time: An Insider's Guide to Buying or Leasing Your Next Car or Truck, ISBN: 0140266704. - Publisher : Viking Pen-guin.

${ }^{13}$ Gutman E., Yagil J., 1993. A practical derived lease rate algorithm // Management science. Providence. Vol. 39. - № 12. - pp. 1544-1551.

${ }^{14}$ Petrolillo P., 1992. Leasing e mutuo: un tentativo di analisi finanzi aria fmalizzata allasceltadé liafonte di fmanziamento. Riv. bancaria. Milano. - A. 48. - № 3. - pp. 71-83.
} 
payments, i.e. the contract of leasing is not determined by economic criteria, and in a form on compliance to legal norms.

In Great Britain and France many agreements are treated as leasing, and in Germany they can correspond to the concept of instalment transaction. In France leasing agreements providing possibility of the option upon termination of the stipulated term (the right of purchase at the residual price), belong to transactions of credit-lease, and such distinction has basic value as transactions like credit-lease are regulated by the state by other methods. ${ }^{15}$ The French legislation does not allow the manufacturer of property to make leasing operations.

State regulation of leasing activities in each country has features. Government bodies not only regulate bank activities, but also exercise control over leasing where leasing is a specific function of banks (Italy, France). In Great Britain, Germany banks are only controlled for the leasing operations which are performed by structures subordinated to them. In France all leasing activities are strictly regulated by the state on an equal basis with banks. In other countries regulation of leasing activity in comparison with bank operations is considerably simplified. ${ }^{16}$

Legislation of Italy, the USA, and France provides special requirements to the leasing mechanism. Leasing agreements are subject to registration in judicial authorities for the purpose of the notification of the certain circle of persons provided by the legislation about the owner of the leasing property, etc. In Great Britain, Germany, Denmark, the Netherlands leasing activity, as a rule, is not regulated and not limited.

As experience has shown, the specific legislation is not defining for leasing development, macroeconomic conditions of the country, the state support of investment activity and leasing as its important form dominate. Optimum conditions for leasing are created in Great Britain, Germany, Ireland, Norway, the USA. So, for example, in Ireland the state subsidies, opportunity to use the accelerated depreciation and other privileges are provided to the leasing companies for leasing stimulation that have benefited the leasing market. As a result Ireland has become the world centre of aircraft leasing, in the country the International centre works for rendering financial services, etc. There are countries where development of leasing is interfered by some restrictions. For example, in Greece leasing of real estate, freight vehicles and buses are forbidden, the brake is also depreciation norms which are regulated by the state.

In 2014 , total new leasing volumes were $€ 275.7$ billion. This represents an increase of $9.5 \%$ compared to 2013 . The portfolio of leased assets (out standings) in Europe grew by $1.7 \%$, reaching $€ 729.6$ billion at the end of 2014 . The UK was the largest European leasing market in 2014, with new volumes worth $€ 60.8$ billion, followed by Germany ( $€ 49.8$ billion), France ( $€ 40.2$ billion) and Italy ( $€ 18$ billion). While the increase in new business volumes was largely driven by Europe's four largest economies, most national leasing markets saw positive results in 2014 with a notable improvement in Southern Europe compared to the previous year (Spain - an increase of 39.92\%, Portugal $30.51 \%$ ). In Poland new leasing volumes were $€ 10.2$ billion, an increase of $21.30 \%$

\footnotetext{
${ }^{15}$ Temin P. 1991. Inside the business: historical perspectives on the use of in-formation, Chicago, UChP. 260 p.

${ }^{16}$ Marvin T. Batte,2003. Precision Farming and Land Leasing Practices Text [Electron resource] / Marvin T. Batte. //Journal of the asfmra. -2003. - [Electron p.], available at: http://www.asfmra.org/wpcontent/uploads/2014/06/200.pdf [accessed: 11.12.2015].
} 
compared to $2013 .{ }^{17}$ In contrast, Austria, Estonia, Latvia, Slovenia, Ukraine and Russia were among the countries, where the recovery of new volumes stalled or saw a downturn.

During the year, European lessors granted new equipment (including vehicles) volumes of $€ 260.3$ billion and new real estate volumes of $€ 15.4$ billion. Similar to the overall market, the equipment sector grew by $9.5 \%$ compared to the previous year, while real estate leasing saw an increase of $9.9 \%$, witnessing the first year of growth since 2010. In 2014, Leaseurope's total penetration rate, measured as the amount of overall new leasing volumes granted to businesses divided by investment in the 24 countries, increased to $13.1 \%$ from $12.3 \%$ in 2013 . When restricted to equipment and vehicles (i.e. excluding real estate from the calculation), the penetration rate stood at $23.5 \%$ compared to $22.1 \%$ in 2013. Automotive assets, i.e. passenger cars and commercial vehicles, accounted for $65 \%$ ( $€ 178.2$ billion) of total new volumes granted during 2014 , remaining the largest individual asset segment of the European leasing market. The passenger car sector performed particularly well, growing by $14.6 \%$ and, according to Leaseurope estimates, European leasing and rental companies purchased some 7.5 million passenger cars in 2014. New leasing volumes for commercial vehicles also increased, albeit at a somewhat slower rate than for passenger cars, gaining $10.6 \%$ in 2014 , to reach new leasing volumes of $€ 49.7$ billion. ${ }^{18}$

Another key growth area included the machinery and industrial equipment segment (making up $17 \%$ of new equipment volumes with new contracts worth $€ 43.6$ billion), which grew by $10.9 \%$. The leasing of smaller ticket items (computers and business machines) increased slightly by less than $1.0 \%$. While the leasing of "other types of equipment", which includes energy generating assets, such as photovoltaic panels, remained relatively flat, the ships, aircraft, railway, and rolling stock segment experienced a decline of $21.9 \%$.

About three quarters of new leasing volumes for equipment (including vehicles) were made to the private sector, with $23 \%$ granted to consumers and $3 \%$ to public authorities. Leasing to consumers was the only client category that has been steadily increasing since 2010. As in previous years, the vast majority of new equipment and vehicle contracts $(73 \%)$ were made for an original contract term between 2 to 5 years, with the average contract size being about $€ 29,400$, a 3\% decrease compared to 2013.

Real estate leasing saw an increase of $9.9 \%$ in 2014 to reach $€ 15.4$ billion, witnessing the first year of growth since 2010. The number of new contracts granted also increased by $3.6 \%$. New leases for most types of buildings experienced double digit growth, notably office buildings, gaining $62.8 \%$, hotels and leisure buildings $23.8 \%$, and retail outlets $14.5 \%$. The largest segment of all property leases was industrial buildings, comprising $34 \%$ of total new real estate leasing volumes. In 2014, new business in this segment grew by $12.7 \%$. Leases of utilities and other types of buildings were the only segments, which contracted by $65.9 \%$ and $5.1 \%$, respectively.

\footnotetext{
${ }^{17}$ Leaseurope. The Voice of Leasing and Automotive Rental in Europe. Annual Survey 2014, available at: http://www.leaseurope.org/uploads/documents/stats/European\%20Leasing\%20Market\%202014.pdf[accessed: 08.01.2016].

${ }^{18}$ Leaseurope. The Voice of Leasing and Automotive Rental in Europe. Key Facts and Figures 2014, available at: http://www.leaseurope.org/uploads/documents/FF\%20Leaseurope\%202014.pdf [accessed: 11.01.2016].
} 


\section{Leasing in Armenia: problems and solutions}

The potential of development of the leasing market in Armenia is very good. Specific gravity of leasing investments remains at a low level despite the high need of Armenian economy for updating of fixed assets so far. However the accruing competition in the market, increase of level of knowledge of potential lessees and need of search of alternative sources of business financing give the grounds to assume that in the next years the market is able to grow several times.

The economic crisis affected not so much quality of a leasing portfolio, as tendencies of development of the leasing market in Armenia. There were changes in demand for leasing by economic sectors. The number of applications for leasing of vehicles which made a considerable share of the market decreased. Demand for leasing services from the company-builders reduced, but the companies which are engaged in infrastructure construction, one of the leaders in demand for leasing of the equipment, as well as mining companies; the volume of leasing contracts grows in the sphere of food production, fishing industry, medical services, the sphere of tourism, appeared a tendency of acquisition of leasing contracts in the sphere of innovations.

For example, when the ACBA Leasing Company ${ }^{19}$, occupying $96 \%$ of the Armenian leasing market in 2009 , only began the activity, the share of leasing contracts in the sphere of agriculture made $70 \%$ of the portfolio, in 2009 - only $4 \%$, and not due to reduction of demand from farms, and at the expense of increase in the share of other branches of business, however since the beginning of 2010 the change in demand structure has been really very considerable. The company provides movable property leasing, and the lion's share of the portfolio - 50\% - made leasing of vehicles: cargo and cars, tractors, special equipment, etc. However after restructuring and diversification of the portfolio during 2009 the share of vehicles leasing was reduced to $36 \%$ at the expense of increase in the share of leasing of the medical equipment $(4.5 \%$ of the general portfolio), the typographical equipment $(8 \%)$, the equipment for the mining industry $(6 \%)$, food industry $(8 \%)$, innovative technologies, and also generators and turbines for small hydroelectric power stations, construction equipment (cranes, graders), office equipment ${ }^{20}$. However at the expense of the share of commercial real estate leasing (this type of leasing is very actual and is in great demand in the international practice), the percentage ratio of different types of leasing will change, in particular, the share of vehicles leasing which is the most perspective direction of leasing in Armenia, will decrease considerably.

The main demand for leasing services, as a rule, shows small and medium-sized enterprises. The work only with big clients did not justify itself so far. In the portfolio of ACBA Leasing there are not many large contracts, demand for them small. Though in the company there is no restriction according to the leasing program, it is possible to

\footnotetext{
${ }^{19}$ USAID's Agribusiness Small and Medium-Sized Enterprise Market Development Program (ASME) in Armenia supported the creation of the ACBA Leasing Company. ACBA Leasing was started in 2003 with USAID support and technical assistance to provide better access to effective term financing for agribusinesses and small and medium-sized enterprises, especially in rural areas where collateral requirements are tougher to meet. The founding shareholders-ACBA Bank, Crédit Agricole of France, the Lebanese Leasing Company, and the International Finance Corporation (IFC), drew up the company charter to emphasize the interest of the leasing company in supporting productive sectors, as well as a focus on financing productive equipment. ${ }^{20} \mathrm{http}: / /$ old.express.am/46_09/economics46.html [accessed: 21.12.2015].
} 
decide on the conclusion of such contracts only in case of presence of the clients with diversified business working in different sectors of the economy. Before the Crisis big clients really gave preference to the bank credits, but then when many businessmen had problems with collateral security, demand for large leasing deals grows ${ }^{21}$. For example, the great demand exists on leasing of the equipment for the mining industry, and it very expensive.

In Armenia leasing services are provided by banks and credit organizations. The leader in the Armenian leasing market is "ACBA Leasing" Credit Organization, whose share amounted to around $64 \%$ in 2014, America bank followed in the second place with $17.12 \%$ market share, and in the third place was VTB Bank (Armenia) with $12.18 \%$ share (Table. 1).

Table. 1. The structure of the Armenian leasing market in 2014 (c/)

\begin{tabular}{|l|r|}
\hline \multicolumn{1}{|c|}{ Name } & Structure $(\%)$ \\
\hline "ACBA Leasing" Credit Organization CJSC & 63,85 \\
\hline "AMERIABANK" CJSC & 17,12 \\
\hline "VTB BANK (ARMENIA)" CJSC & 12,18 \\
\hline "SME Investments" Universal Credit Organization CJSC & 2,63 \\
\hline "CONVERSE BANK" CJSC & 2,25 \\
\hline "CARD AgroCredit" Universal Credit Organization CJSC & 0,73 \\
\hline "ARARATBANK" OJSC & 0,59 \\
\hline "FARM CREDIT ARMENIA" Universal Credit Organization Commercial Cooperative & 0,58 \\
\hline "AGROLEASING LEASING CREDIT COMPANY" LLC & 0,07 \\
\hline "ARMBUSINESSBANK" CJSC & 0,0033 \\
\hline
\end{tabular}

Source: the authors, based on the official data provided by the Armenian credit organizations and commercial banks.

The amount of leasing transactions of the Armenian credit organizations increased by 4.4 percent previous year to 8.5 billion drams, according to ARKA news agency's bulletin "Credit Organizations of Armenia" for the IV quarter of 2013. Of 33 credit organizations only six offered leasing previous year. The leading organization by size of leasing deals was ACBA Leasing that accounted for about $93.59 \%$ of leasing transactions. In 2013, its leasing operations stood at about 8 billion drams, an increase of 3.4 percent when compared with 2012. It was followed by SME Investments - 207 million drams, Farm Credit Armenia - 157.4 million drams, down 6.2\%, CARD AgroCredit - more than 84.9 million drams, down $33.7 \%$, Unileasing - 74.2 million drams, down $35.1 \%$ and Agroleasing - 22.1 million drams, down $46.5 \%{ }^{22}$.

In 2014 the leasing portfolio of ACBA Leasing amounted to over 9 billion drams, or $94.09 \%$ of the leasing transaction scurried out by the Armenian credit organizations. It was followed by SME Investments, whose leasing portfolio was about 389 million drams, CARD AgroCredit - 107.6 million drams, Farm Credit Armenia - 85.7 million drams and Agroleasing - 9.7 million drams (Table. 2).

\footnotetext{
${ }^{21} \mathrm{http}: / /$ old.express.am/20_10/lizing20.html [accessed: 14.12.2015].

${ }^{22} \mathrm{http}: / /$ www.armbanks.am/en/2014/02/26/72071/ [accessed: 17.12.2015]
} 
Table 2. Leasing portfolios of the Armenian credit organizations in 2014 (thousand drams and \%)

\begin{tabular}{|l|r|r|}
\hline \multicolumn{1}{|c|}{ Name } & Value(thousand drams) & \multicolumn{1}{|c|}{ Structure (\%) } \\
\hline "AMERIABANK" CJSC & 2528848 & $53,27 \%$ \\
\hline "VTB BANK (ARMENIA)" CJSC & 1799339 & $37,49 \%$ \\
\hline "CONVERSE BANK" CJSC & 332003 & $6,99 \%$ \\
\hline "ARARATBANK" OJSC & 86697 & $1,83 \%$ \\
\hline "ARMBUSINESSBANK" CJSC & 493 & $0,01 \%$ \\
\hline
\end{tabular}

Source: the authors, based on the official data provided by the Armenian credit organizations.

Ameriabank occupies the leading position among the Armenian commercial banks providing leasing services. The leasing portfolio of Ameriabank exceeded 2.5 billion drams in 2014 and amounted to $53.27 \%$ of the leasing transactions conducted by the commercial banks of Armenia. VTB Bank (Armenia) was the second by its leasing portfolio of around 1.8 billion drams in value. It was followed by Converse Bank- 332 million drams, Araratbank - about 87 million drams and Armbusinessbank - 493 thousand drams (Table. 3).

Table 3. Leasing portfolios of the Armenian commercial banks in 2014 (thousand drams and \%)

\begin{tabular}{|l|r|r|}
\hline \multicolumn{1}{|c|}{ Name } & $\begin{array}{c}\text { Value(thousand } \\
\text { drams })\end{array}$ & $\begin{array}{c}\text { Structure } \\
(\%)\end{array}$ \\
\hline "ACBA Leasing" Credit Organization CJSC & 9432406 & $94,09 \%$ \\
\hline "SME Investments" Universal Credit Organization CJSC & 388941 & $3,88 \%$ \\
\hline "CARD AgroCredit" Universal Credit Organization CJSC & 107615 & $1,07 \%$ \\
\hline $\begin{array}{l}\text { "FARM CREDIT ARMENIA" Universal Credit Organization Commercial } \\
\text { Cooperative }\end{array}$ & 85664 & $0,85 \%$ \\
\hline "AGROLEASING LEASING CREDIT COMPANY" LLC & 9726 & $0,10 \%$ \\
\hline
\end{tabular}

Source: the authors, based on the official data provided by the Armenian commercial banks.

Despite the available prospects, the leasing market in Armenia develops insufficient dynamically. There are various reasons which are slowing down its development, among which both backwardness of the secondary market of the equipment and vehicles, and imperfection of the legislative base, and many others. The leasing companies are ready to finance transactions on purchase of the equipment which was in the use if it is on sale by the official dealer giving a guarantee on service both the new and used equipment providing deliveries of spare parts, etc., but there are not enough such companies. Sometimes when purchasing equipment from foreign companies which do not have representation in Armenia there are problems with obtaining information on the supplier that does not also give the chance of the conclusion of the leasing contract. Leasing is not only possibility of acquisition of the equipment, but also opportunity of attraction of the qualitative equipment. It is favourable to the companies financing leasing transactions that clients acquire the reliable modern equipment. Because breakage, defect or the insufficient productivity of the equipment are always reflected in risks of the project in general. For this reason market participants have serious approaches not only to potential borrowers, but also to suppliers of the equipment and are interested in development of the secondary market of the equipment. If in the country the secondary market of the equipment and vehicles works well, repurchase agreements practice more often, it will reflected in development of the leasing market. 
Leasing is favourable to all: lessors gain income from conducting such business activity, lessees - opportunity to modernise the fixed assets even earlier, than make for them payment, and the state - the income in a type of tax payments. Violation of balance of interests makes leasing unprofitable to one of the parties, and, so inexpedient in principle. The accelerated depreciation for the fixed assets, which are leasing subject, is provided in the legislation of a number of countries for the sake of balance of interests of all parties at payment of income tax. In Armenia first of all the imperfect tax law disturbs leasing development. Activity of players of the leasing market is regulated by the Civil Code of $\mathrm{RA}^{23}$ and the RA Law on Credit Organizations ${ }^{24}$. However the current legislation and provisions forbid to apply methods of the accelerated depreciation by economic entities that are very widespread in the international practice. Possibility of optimization of the depreciation sums allows the enterprise to influence financial results of production and economic stability of the enterprise purposefully. Now straight-line method of depreciation of fixed assets is used at the Armenian enterprises that make leasing non-competitive in comparison with the credit.

Leasing forms the tax relations on different signs of rent operations on which the state conducts ambiguous fiscal policy. In some countries preferential terms on the property tax of the rented assets are offered, thereby stimulating leasing. Most of all preferential terms on a value-added tax of leasing operations are practiced. However in leasing stimulation an important role is played by regulation of the relations on income tax.

Speaking about the factors limiting leasing development it should be noted also that payments for leasing in Profit and Loss Statement of the domestic companies are not considered in expenses. Only a percent of rise in price of leasing property belongs to expenditure side.

It is necessary to make some changes to the current legislation for the purpose of underlining of advantages of leasing. As development of leasing will lead to modernization of fixed assets, domestic producers will be able to use the modern, technologically advanced equipment in production, thereby making competitive and high-quality production.

\section{Conclusions}

In Armenia the use of leasing as a form of financing for development of innovation activities of the enterprises is significantly limited. It is caused, first, by incompleteness of application of existing forms of leasing and, secondly, insufficient state support for the leasing companies which are engaged in financing of innovation projects. The fullfledged infrastructure of the leasing market is undeveloped that also interferes with process of establishment of long-term leasing programs and by that creates considerable risk factors at the organization of leasing operations. In this regard it is necessary to create favourable conditions for development of leasing in Armenia, based on experience of the advanced European countries, in particular for the purpose of improving a legal

\footnotetext{
${ }^{23}$ Civil Code Of The Republic Of Armenia, available at: http://www.arlis.am/documentview.aspx?docid=74658 [accessed: 11.12.2015] (in Armenian).

${ }_{24}$ REPUBLIC OF ARMENIA LAW ON CREDIT ORGANIZATIONS, available at: https://www.cba.am/EN/lalaws/credit.pdf [accessed: 12.12.2015].
} 
framework of leasing regulation in Armenia it is expedient to fill the gaps in the legislation with adoption of law on leasing, along with harmonization of requirements of all legal acts existing in the Republic relating to the organization of leasing; to intensify motivational processes of leasing by legal levers, improving activities to purchase assets by lessees, deductions of rent payments, possession, operation and modernization of rental property; to expand a framework of economical and legal regulation of the leasing relations, including not only activity of direct participants of leasing, but also indirect (intermediaries, insurers, etc.), as in the presence of normal economical and legal relations between these participants continuous and effective implementation of leasing transactions is guaranteed. The state tax policy is an effective remedy of activisation of the leasing market. In particular, application of property tax benefits on the object of leasing, and also income tax benefits on interest income of leasing transactions on the one hand reduces tax revenues in the state budget, however, on the other hand, due to fiscal privileges the financial market becomes more active that leads to an increase in income taxes from leasing transactions. Besides, activisation of the leasing market and therefore growth of tax revenues from leasing is influenced significantly by application of the accelerated depreciation policy and reduction of terms of the leasing contract, as forms the basis for permission under the tax law to use alternative ways of charge of wear of leased assets along with application of straight line depreciation of fixed assets. The above mentioned recommendations will promote further development of leasing in Armenia and will allow lessors to participate in leasing of fixed assets for innovative companies.

\section{References}

Bazrod Mark S.,. Puncturing the 15 Myths of Software Leasing// Journal of Equipment Lease Financing Number 3 Fall, 2006, pp.1-8.

Clark T., Leasing Finance, 3nd ed., 275 pp. Publisher: Euromoney Publications, PLC Pub. Date: January 2004.

Contino M. Richard, The Complete Equipment-Leasing Handbook, Amacom Books, - 2002. 480p.

Crawford Richard D., Intellectual Property: the Leasing Industry Future // Journal of Equipment Lease Financing Number 2 Fall, 2002, pp. 18-27.

Durinck E., Jansen K., Laveren E., Huile C., Leasing and the pie approach to capital structure. Tijdschr. vooreconomieen management. Leuven. - Jg. 35. - № 4, 1990, pp. 387-405.

Gutman E., Yagil J., A practical derived lease rate algorithm // Management science. Providence. - Vol. 39. - № 12. - 1993, pp. 1544-1551.

Hugel R., 1996. Geschlossene Immobilienfonds: Interne Zinsfuß Methode und Steuerpotential // Bank. Köln. - № 6, 362-367.

Humphreys P., Mulligan H., United States: Lease Securitization: New Challenges for Issuers, McDermott Will\&Emery, 2005, available at: http://www.mondaq.com/unitedstates/x/31971/Structured+Finance/Lease+Securitization+New+Ch allenges + for+Issuers [accessed: 18.12.2015].

International leasing finance seminar. Euromoney - London - $2008-114 p$.

Krinsky I., Mehrez A., Principal-agent maintenance problem. Naval research logistics. Wash. Vol. 36. - № 6, 1989., pp. 817-828.

Lease and Hire Purchase Contracts, UK GAAP, 7th ed., L.: Ems and Young, 2006, 428p. 
Marvin T. Batte,. Precision Farming and Land Leasing Practices Text 2003, [Electron resource] / Marvin T. Batte. //Journal of the asfmra. -2003. - [Electron p.], available at: http://www.asfmra.org/wp-content/uploads/2014/06/200.pdf [accessed: 11.12.2015].

Petrolillo P., Leasing e mutuo: un tentativo di analisi finanzi aria fmalizzata allasceltadé liafonte di fmanziamento. Riv. bancaria. Milano. - A. 48. - № 3. - 1992, pp. 71-83.

Ricketts M., The Economics of Business Enterprise: An Introduction to Economic Organisation and the Theory of the Firm, Edward Elgar, 2003, 592p.

Sutton R., Don't Get Taken Every Time: An Insider's Guide to Buying or Leasing Your Next Car or Truck, ISBN: 0140266704. - Publisher : Viking Pen-guin 1997.

Temin P.. Inside the business: historical perspectives on the use of in-formation, Chicago, UChP. 1991, 260p.

Veatch William S.,. Software Leasing: the Intricacies of the Intangible // Journal of Equipment Lease Financing Fall. - Vol. 14. - N. 2, 1996, pp.21-28.

\section{Streszczenie}

$W$ artykule przedstawiono możliwość wykorzystania leasingu jako instrumentu finansowania działalności innowacyjnej. $W$ dzisiejszych czasach kwestia poszukiwania nowych sposobów finansowania działalności innowacyjnej, która jest głównym czynnikiem konkurencyjności przedsiębiorstw, ma szczególne znaczenie. Artykut przedstawia zalety leasingu jako mechanizmu finansowania działalności innowacyjnej oraz rolę innowacyjnego leasingu $w$ nowoczesnych warunkach. Autorki przeprowadzily również analizę porównawcza przepisów dotyczacych leasingu $w$ wielu krajach europejskich, a takze analize europejskiego rynku leasingu pod względem struktury $i$ aktualnych trendów rozwoju. Wyszczególniono główne problemy zaktócajace rozwój leasingu w Armenii. Dodatkowo na podstawie najlepszych praktyk europejskich przedstawiono zalecenia, które promuja korzystanie z leasingu do stymulacji działalności innowacyjnej przedsiębiorstw w Armenii.

Słowa kluczowe: Leasing, innowacje, finansowanie, inwestycje, badania i rozwój

\section{Corresponding author:}

\section{Dr inż. Agnieszka Parlińska}

Warsaw University of Life Sciences - SGGW,

Faculty of Economic Sciences, Department of European Policy, Public Finance and Marketing, Nowoursynowska 166,

02-787 Warsaw, Poland,

e-mail: agnieszka_parlinska@sggw.pl;

\section{Lilya Avetisyan, PhD}

Eurasia International University, Management and Information Technology Department, Azatutyan 24/2,

0014 Yerevan, Armenia

e-mail: likaavetisyan@yahoo.com 